\title{
THE EFFECT OF STAD UPON STUDENTS WITH DIFFERENT LEVEL OF SELF ESTEEM TOWARD READING COMPREHENSION OF ELEVENTH GRADE STUDENTS OF SMAN 1 KEDIRI TABANAN IN THE ACADEMIC YEAR 2013/2014
}

\author{
Adi, I N. S. M. \\ Language Education Department, Post-Graduate Program \\ Ganesha University of Education \\ Denpasar, Indonesia \\ e-mail: ming_glth@yahoo.com, \\ Padmadewi, N. N. \\ Language Education Department, Post-Graduate Program \\ Ganesha University of Education \\ Denpasar, Indonesia \\ e-mail: nyoman.padmadewi@pasca.undiksha.ac.id \\ Ratminingsih, N. M. \\ Language Education Department, Post-Graduate Program \\ Ganesha University of Education \\ Denpasar, Indonesia \\ e-mail:made.ratminingsih@pasca.undiksha.ac.id
}

\begin{abstract}
The purpose of the study is to investigate the effect of STAD treatment on reading comprehension in eleventh grade students of SMAN 1 Kediri Tabanan in academic year 2013/2014. Students' self esteem was also put into consideration and was also investigated as the moderator variable. There were 7 classes as the population and by using intact group random sampling, two classes were chosen as the samples of the investigation and were divided into experimental and control group. In total, there were seventy six students who were selected as the representative of the whole population. To collect the data, the study used reading comprehension test which was administered at the end of teaching sessions. In investigating the result, two statistical methods were applied namely descriptive and inferential statistics by using t-test, product moment and one way ANCOVA. At the end of investigation, it was found that, first, there was a significant difference in reading comprehension between the students who were treated by using STAD and the students who were treated by conventional method. Second, viewed from students self esteem which gave minimum contribution toward the difference of reading comprehension 's score between STAD class and conventional class, it was found that there was no significant correlation between self esteem and teaching method, third there was significant correlation between students' self esteem and reading comprehension for all of the students who were taught by STAD and conventional method, there was no correlation between students' self esteem and reading comprehension for the students who were taught by STAD. Last, there was significant correlation between students' self esteem and reading comprehension for the students who were taught by conventional method.
\end{abstract}

Keywords: Students Team Achievement Divison (STAD), self esteem, reading comprehension, conventional method.

\section{INTRODUCTION}

In Indonesia, English has been considered as the first foreign language taught at school as compulsory subject. Based on Indonesian Government Regulation No. 19 of 2005 (Peraturan Pemerintah Republik Indonesia no 19 tahun 2005), English subject has been included in national final examination for junior high school grade and senior high school in Indonesia. For Elementary school, TEFLIN (The 
Association of Teaching English As A foreign Language In Indonesia) recommend that English should be put as local material to be taught in school, it means English must exist on Elementary school schedule. In other part, it is also stated that curriculum for faculty level in Indonesia must include English as compulsory subject. In Indonesian Republic Act of 2003 (Undang-Undang No 20 Republik Indonesia Tahun 2003) about national education system, it is stated that Foreign language can be used as a language of instruction in the specific educational unit to support learners' skill in using foreign language. One consideration in choosing English as compulsory subject in school is English as a means of international communication is the most commonly used language in the sciences.. Many scientific articles are written in English. These facts lead the government to support learners with English language mastery in order to help them to maintain their education.

There are 4 language skiils need to be learnt in English, they are listening, reading, speaking and writing. From 4 language skill of English, reading is chosen to be research variable. The importance of reading can be captured from the authentic reason of reading. Nutall (1985) states that the authentic reason of reading is to get the message of a writting text, the message can be in form of facts, ideas, enjoyment and feelings of family communication (letter). In general, as stated by Cunningham and Stanovich (2011), reading affects someone cognitive development, they mentioned that the nature of reading are reciprocal and exponential, the result of reading habit such as vocabulary mastery and knowledge about the content of text will be accumulated time by time. The accumulation will give impact to development of cognitive capabilities. Particularly on academic field, Grabe and Stoller in Murcia (2001) also state 4 purposes of reading for academic purpose, those are : (1) reading to search for information, (2) Reading for general comprehension, (3) Reading to learn new information, (4) reading to synthesize and evaluate information. Moreover, Alyousef (2005) states that reading becomes important for learners to receive information or knowledge through printed documents such as scientific text, technical manuals and other printed materials. Books, magazines and even the Internet are great learning tools which require the ability to read and understand what is read. As stated above, to be able to maintain the process of learning, students need to be able to have good ability in reading, since reading can help them to receive knowledge suitable to their needs through printed source, the process and good habit of reading also can help students to develop their cognitive capabilities.

Nevills (2004) mentions that reading skill is composed of two main processes, these are decoding and comprehension. Decoding is process of connecting letters series become the suitable unit of speech that the letters represent in order to make sense of a print or text. Comprehension is a process of making meaning of what readers read, the process involves higher cognitive order and linguistic reasoning including intelligence, vocabulary and syntax. Pang (2003) also states that reading consists of two related processes: word recognition and comprehension. Word recognition is a manner of reading which derives from direct perception of familiar words or group of letters in the text, and comprehension is the process of deriving meaning from connected text which involves word knowledge (vocabulary) as well as thinking and reasoning. Pang (2003) states that reading provides opportunities to study language; vocabulary, grammar, punctuation, and the way we construct sentences, paragraphs and texts.

Reading, in relation to learning a language as foreign or second language, has important role in development of literacy skill in L2, as Geva (2006:1) states that children's L1 reading skill contributes across diverse languages and writing systems. This also means that reading skill influences the development of literacy skills in L2 and bilingual contexts. According to Ediger in Murcia (2001), reading is important skill for second language learners in academic context. It is as the result of the increase number of children worldwide who learn English as second language, and also the result of many countries make English language instruction mandatory from younger age such as in korea and taiwan. In Indonesia, several schools have taught English to their students from early age, the school which is categorized as international school has their students speak in English as second language in their daily activities. In other public school in Indonesia, English remains as a foreign language which is used and taught in certain schedule, not in their daily conversation. Particularly in SMAN 1 Kediri Tabanan, English is taught twice a week for every class. Based on the observation done by the researcher, in SMAN N 1 Kediri Tabanan, English lesson is learnt by students through using students' work sheet (Lembar Kerja Siswa) which contains different materials in every chapter. In every chapter of the LKS, there must be reading comprehension text and several 
questions related to the text. In teaching learning process, the teacher requires the students to read the text and answer individually the questions related to the text, they are expected to be able to understand how to answer the questions by understanding the text, teacher also asks students to actively mention every problem related to the text. The communication occurs only between the students to teacher, there is no communication between students to students. This situation keep the class under the teacher's control, some students response positively toward the teaching method applied by the teacher, they who have better understanding toward the material give active response in class, on other side more students who have problem in understanding the material keep silent and avoid having communication with the teachers, they wait until the questions is answered by the teacher or other students, some of them have no idea on how to answer the questions. The problem is that students' different understanding and insufficient discussion opportunities make the teaching learning process focus only on teacher's explanation and discussions from few students who have relative better achievement than the others, those then take the active role in class activities. The rest of the students become passive and follow the active ones. When teacher randomly asks one by one student to answer the questions, some students cannot answer, they even have no understanding about the question. This unbalance situation causes the teaching learning process remains as a routine to fulfill the schedule, it gives insufficient understanding to all students in class, it is only several students get the benefit. This situation is uncomfortable for several students; some of them avoid having eye contact with the teacher in order to avoid being pointed by the teacher to answer the questions. Overall the class situation becomes rigid and passive.

Reading problems in ESL/EFL class according to Costantino (1999) are poor ability in reading $\mathrm{L} 1$, lack proficiency in $\mathrm{L} 2$, incorrect reading strategies in L2. These cause the learners may find some difficulties in process of comprehending the text. Unfamiliar scripts, writing systems, and unfamiliar cultural material may occurred, learners' inability to connect ideas in a passage. In accordance to self esteem factor, they fell ashamed to state their misunderstanding to the teacher, because rather than feeling hurts by showing their misunderstanding and to be heard by all class, they prefer to keep silent and let the teacher and other students comprehend the text and answer the questions.

Some techniques of cooperative learning can be used to facilitate the problem stated above. According to Thousand, Villa and Nevin (1994) in a cooperative learning environment, learners discuss subject matter, help each other learn, and provide encouragement for member of the group. Promotes positive interdependence, where learners perceive that their success or failure lies within their working together in a group. Promote more positive attitudes toward the instructional experience than competitive or individualistic methodologies. Huda (2013) mentioned that the synergy occurred in cooperative situation gain better learning motivation rather than the competitive individual situation. STAD is part of cooperative learning method that is applied by the researcher to overcome the problem, as Slavin (2005) mentioned that STAD facilitates students with cooperative situation where they can solve their problem within the group. Each student has responsibility to help each other to understand the material in order to achieve good group score. When the researcher apply STAD in class, the situation become active and noisy, students actively share and discuss their problem within the group, they argued their opinion, and they help each other within the group to understand how to answer the questions. The students enjoy STAD situation, they feel comfortable to express their problem and opinion to another students in their own group. They also feel comfortable to invite the researcher to their group and ask several questions about the material, and discuss their problem to the researcher. When researcher ask each group to state their answer related to reading comprehension questions, group with different answer can express their opinion and defend it. The overall class situation becomes active and unpredictable. Through STAD method applied by researcher, students get sufficient opportunities to share and discuss their problem, students also help each other to understand how to answer the reading comprehension questions, not only help each other, they also responsible to ensure that they have same understanding with other in the same group. They realize that each student's score will influence group's score and each group competes with another to get best group score. This cooperative and competitive situation helps students to get better achievement in reading comprehension.

As stated above, different method applied by teacher in class can cause different students behavior and performance, and also it influence different students' achievement toward the material. However, 
it is not only teaching method that affects students' achievement, but also another factor can affect it. Ellis (1997), in general, mentioned that there is factor that affects learner in learning language as second or foreign language. That is individual learners factor which can be grouped into general and personal factors. General factors are variables possessed by all learners that are age, aptitude, cognitive style, motivation and personality. Personal factors can be divided into group dynamic, attitude to the teacher and course material, and individual learning techniques. Both general and personal factors have social, cognitive and affective aspects. Social aspects concern with relationship between learners and another speaker, cognitive concern with the problem solving used by the learners and affective concern with learners' emotional responses aroused in learning process.

Brown (1980) has noted the importance of considering the affective aspects in language learning. He also asserts that in second language acquisition, the most fundamental side of human behavior will be omitted if teaching process is based only on cognitive considerations. Brown (2000) in Soureshjani (2011) also states that reading as an important source of input for second language acquisition is very susceptible to be affected by affective variables. Self-esteem, self-confidence, knowledge of one's self, and the belief about one's own capabilities are all examples of affective factors. In addition Andreas (2003) mentions that some variables of affective domain are found as having a high impact on the success in EFL/ESL learning. Gaskin (1996) in Soureshjani (2011) also mention that, emotional involvement has a significant impact on comprehension to motivate the act of reading.

Self esteem is one of affective factors. According to Bailey (in Ellis, 1986) in group dynamic, learners do comparison of themselves to another learners within the group, in this case is classroom. This comparison may results successful self image or unsuccessful self image. Their self image will affect the mental response to learning process which then will influence their effort in participating learning process. The result that is expected is that learners are able to build successful self image that will help them to have high self esteem, and they can participate the learning process well.

Moreover, Krashen (1995) mentioned some variables which comprise the affective domain of language learning. He also lists three basic factors that underlie the affective filter. They are; motivation, self confidence \& self esteem, and anxiety. In other side, Brown (1980) considers numbers of affective personality factors under the affective domain of second language acquisition. Those factors are self esteem, inhibition, risk taking, empathy, extroversion, and motivation.

Clay Tucker (2004) defined self-esteem is a set of attitudes and beliefs that a person brings with him or herself when they face the world. It includes beliefs as to whether he or she can expect success or failure, how much effort should be put forth, whether failure at a task will "hurt," and whether he or she will become more capable as a result of different experiences. In psychological terms, self-esteem provides a mental set that prepares the person to respond according to expectations of success, acceptance, and personal strength. In addition, self esteem is thought to be relatively stable in a mature adult, and is resistant to change except by active and extended therapy. A similar definition was given by Coopersmith (1967 as cited in Brown, 1980) self esteem is a personal judgment of worthiness that is expressed in the attitudes that the individual hold toward himself. This factor then becomes a consideration of the research because self esteem is an important factor that can influence a student to encourage themselves in learning English. A high self esteem can make learners feel confidence of themselves and dare to involve in oral production without being worried of making mistake.

Based on the statements above, it can be said that reading is important in general life or in academic purposes, the authentic reason of reading is to be able to get information from written text, people search for information that can help their life through reading. In academic purposes reading is important for students to help them to search and learn information that is needed for their academic activities, they learn how to comprehend, synthesize and evaluate information through reading, particularly in senior high school grade, reading activity done by students is reading to comprehend the text, they no longer do reading to decode the letter become understandable text, reading for them is reading to obtain and to understand the whole information of a text. However, the fact that in the class situation, teaching method applied by teacher affects students' performance and behavior, and students' performance and behavior will affect the success of improving students' reading comprehension. Moreover, not only teaching method but also students' personal affective factor such as students' self esteem that affect the success of improving students' reading comprehension. 
Considering the facts and statements above, the researcher is interested in finding out the effect of STAD on reading comprehension achievement of eleventh grade students with their different level of self esteem of SMA N 1 Kediri, Tabanan. STAD is compared with the previous technique applied by the teacher to the class, where the teacher apply conventional technique and take role as the center of the class, the teacher mostly give instruction to learners to answer the questions in the LKS book individually without facilitating them to have equal discussion, STAD according to Freeman (2000) gives more opportunities for students to do discussion and not to think individualistic but rather cooperatively within the group. This opportunity also allows them to learn from another learners in a group who are mixed, high self-esteem and low self-esteem, different ethnic groups, different proficiency. By measuring students' self esteem through administering self esteem questionnaires, the researcher classify students based on their level of self esteem then the researcher figure out the effect of self esteem level on students reading comprehension achievement for those who are taught by using conventional method and those taught by STAD method.

\section{METHOD}

There were 7 classes of eleventh grade students of SMAN 1 Kediri Tabanan in academic year 2013/2014.Two classes were chosen the population of the study, they are XI IPS 1 and XI IPS 2. each class consisted of 38 students. XI IPS 1 was chosen to be the experimental group, that is the group which was treated by STAD method, and XI IPS 2 was the control group, the group which was treated by conventional method.

The research procedure was divided into three phases, the first was the preparation phases, researcher prepare the instrument of research such as reading comprehension test, and self esteem questionnaires, the instrument has been examined by the expert judges, then it was tried out to XI IPS 3 to measure the validity and reliability of each items of the test. The reading comprehension instrument was based on the syllabus and the blue print of the instrument. Designing lesson plans and worksheet for experimental and control class. Asking permission to Headmaster and setting up the schedule with the English teacher. The research was done between March to April 2013. There were six meetings for each class. the first meeting, researcher distributed self esteem questionnaires to the students to answer, the second until fifth meeting were the treatment meetings, the sixth meeting was the reading comprehension test.

The second phase was implementation of lesson plan and worksheet that had been prepared on the preparation phase. The content of material for both classes was the same, however the learning process between those two classes was different. The difference can be seen from the table below :

Table 1. Research Implementation

\begin{tabular}{|c|c|c|c|}
\hline No & Component of Experiment & Experiment Class & Control Group \\
\hline 1 & Teaching material & $\begin{array}{l}\text { Narrative, Recount, and } \\
\text { Descriptive text }\end{array}$ & $\begin{array}{l}\text { Narrative, Recount, and } \\
\text { Descriptive text }\end{array}$ \\
\hline 2 & Teaching technique & STAD technique & Conventional technique \\
\hline 3 & Time allotment & $\begin{array}{l}2 \times 40 \text { minutes, twice a } \\
\text { week. The period of the } \\
\text { research were between } \\
\text { March and April }\end{array}$ & $\begin{array}{l}2 \times 40 \text { minutes twice a week. } \\
\text { The period of the research } \\
\text { were between March and } \\
\text { April }\end{array}$ \\
\hline 4 & Subject teacher & The researcher & The researcher \\
\hline 5 & Learning process & $\begin{array}{l}\text { 1. Teacher explains the } \\
\text { material to the class } \\
\text { 2. Teacher asks the } \\
\text { students to form } \\
\text { group consist of } 4-5 \\
\text { members } \\
\text { 3. Students are requested } \\
\text { to read the passage }\end{array}$ & $\begin{array}{l}\text { 1. Teacher explains the } \\
\text { material to the class } \\
\text { 2. Teacher asks students to } \\
\text { read the passage } \\
\text { individually } \\
\text { 3. Students are requested to } \\
\text { find difficult features on } \\
\text { passage (difficult word, }\end{array}$ \\
\hline
\end{tabular}




\begin{tabular}{|c|c|c|c|}
\hline & & $\begin{array}{l}\text { and find difficult } \\
\text { words and grammar } \\
\text { features within the } \\
\text { group. } \\
\text { 4. Students discuss the } \\
\text { problem obtained } \\
\text { from the passage with } \\
\text { their group members. } \\
\text { 5. Teacher asks students } \\
\text { to dismiss the group } \\
\text { and answer the } \\
\text { questions related to } \\
\text { passage individually. } \\
\text { 6. Teacher and students } \\
\text { discuss the answer } \\
\text { together. } \\
\text { Teacher score the } \\
\text { students answer sheet. } \\
\text { The individual score } \\
\text { will influence group } \\
\text { score. The group final } \\
\text { score is counted. }\end{array}$ & $\begin{array}{l}\text { confusing grammar) and } \\
\text { ask it to the teacher. } \\
\text { 4. Teacher explains the } \\
\text { answer of question } \\
\text { obtained by students } \\
\text { 5. Teacher asks students to } \\
\text { answer questions related } \\
\text { to the passage } \\
\text { individually } \\
\text { 6. Teacher and students } \\
\text { discuss the answer } \\
\text { together. } \\
\text { Teacher score students } \\
\text { answer sheet. The score } \\
\text { obtained is individual } \\
\text { score }\end{array}$ \\
\hline 6 & Type of exercise & Multiple choice & Multiple choice \\
\hline 7 & Items & 10 & 10 \\
\hline 8 & The frequency of exercise & 4 & 4 \\
\hline 9 & Reading comprehension test & Multiple choice & Multiple choice \\
\hline 10 & $\begin{array}{l}\text { Number of reading } \\
\text { comprehension test }\end{array}$ & 60 & 60 \\
\hline
\end{tabular}

The last phase was the analyzing phase. The researcher analyzed the reading comprehension test result and self esteem questionnaires. .

After obtaining the scores from the both the experimental and control groups, two statistical techniques were applied to analyze the data. The first was descriptive statistical analysis and the second was inferential statistic analysis. In descriptive statistics, median, mode, range, mean score and standard deviation were calculated. In inferential statistics, the T-test, product moment and one way ancova were administered. To be able to administer inferential statistics, normality and homogeneity test must be administered to measure the normal distribution and homogeneity of variance of the data. By operating SPSS 15.0 for windows, it found that all of the data were normal and homogenous

\section{FINDINGS AND DISCUSSIONS}

There were three discussions part in findings and discussions chapter. The first discussed about the significant difference in reading comprehension between the students who are treated by STAD and those who are treated by conventional method, the second discussed about the significant interactional effect between STAD and the students' reading comprehension viewed from their self esteem and the third discussed about the significant correlation between students' self esteem and students reading comprehension. 


\section{For hypothesis 1}

There is a significant effect in reading comprehension between the students who are treated by using STAD treatment and those who are not treated by using STAD.

According to the result of t-test testing, the value of probability or sig was 0.00 which was lower than the significance value of $t$ table 2.00 (degree of freedom 74 ((38+38)-2) and 0.05 for sig. Level)). It could be interpreted that $\mathrm{Ha}$ which mentioned that there is a significant effect in reading comprehension between the students who were treated by using STAD treatment and those who were not treated by using STAD was accepted.

The descriptive statistic analysis indicated that the mean score of the students' reading comprehension treated by using STAD was 6.57 while the mean score of the students' reading comprehension without STAD was 5.61. The result of t-test proved that students' reading comprehension treated by STAD was higher than the students' reading comprehension without STAD treatment. It could be concluded that there was a significant effect on the implementation of STAD treatment on the students' reading comprehension.

\section{For hypothesis 2}

There is a significant correlation between the STAD and the students' reading comprehension viewed from their self esteem

Dantes (2012) mentioned that in the situation of an independent variable (STAD) influenced a dependent variable (reading comprehension), where it was also known that moderator variable (self esteem) as continuum variable also influenced the dependent variable (reading comprehension), the calculation that could be used to find out correlation between all of those three variable was by calculating the correlation between STAD and reading comprehension with considering students' self esteem. The calculation which can be used is one way analysis covariate.

Since students showed different score of self esteem and they showed the explicit variety, it was inappropriate to classify the students according to their level of self esteem, in order to find the correlation between STAD and reading comprehension viewed from students self esteem. As the solution, Dantes (2012) and Koyan (2012) mentioned Ancova analysis. In ancova analysis, the researcher measure how significant self esteem contribute in the different score obtained by students in STAD class and students in conventional class. Thus the interactional correlation between STAD and reading comprehension by considering students' self esteem could be figure out.

From the calculation above, it was found that $\mathrm{F}=0,197$, which was lower than $\mathrm{F}$ table $=4.00(\mathrm{db} 1$ : 74 sig. value 0,05 ). From the calculation it could be interpreted that Ho was accepted. It meant that after being controlled by students' self esteems score, there was no significant difference on students reading comprehension for those who were taught by using STAD and those who were taught by using conventional method.

\section{For hypothesis 3}

There is a significant correlation between students' self esteem and students reading comprehension.

For all of students who were taught by using STAD method (experiment class) and students who were taught by using conventional method (control class), the result obtained from $\mathrm{t}$ - test calculation showed sig value was 0,34 which was higher than $r$ table $0,22(\mathrm{~N}=76$; sig. level $=0.05)$. From the result, it could be interpreted that Ho was rejected, and Ha which mentioned that there was positive correlation between students' self esteem and reading comprehension for all of the students who were taught by STAD and conventional method was accepted.

For students who were taught by using STAD method (experiment class), the result obtained from $\mathrm{t}$ - test calculation showed sig value was 0,00 which was lower than $\mathrm{r}$ table $0,32(\mathrm{~N}=38$; sig. level $=$ 0.05). From the result, it could be interpreted that Ha was rejected while Ho which mentioned that there was no correlation between students' self esteem and reading comprehension for the students who were taught by STAD was accepted.

For students who were taught by using conventional method (control class), the result obtained from t- test calculation showed sig value was 0,479 which was higher than $r$ table $0,32(\mathrm{~N}=38$; sig. 
level $=0.05$ ). From the result, it could be interpreted that Ho was rejected, and Ha which mention that there was positive correlation between students' self esteem and reading comprehension for the students who were taught by conventional method was accepted.

\section{CONCLUSION AND SUGGESTIONS}

The objectives of the study were to find out whether there or not: (1). The significant difference of students' reading comprehension with STAD treatment and without STAD, (2). The interactional correlation between the teaching treatment and students' reading comprehension viewed from students self esteem, (3). The significant correlation between students' self esteem and students reading comprehension.

The research was done by using multiple variable factorial designs and grouped into: (1). A1: Group of students treated by STAD, (2). A2: Group of students not treated by STAD (conventional teaching method only)

T-test, product moment and one way ancova were selected to analyze the data, since there was an interactional between the treatment and the self esteem. Furthermore, descriptive analysis was also conducted in order to measure the mean, standard deviation, mode and median. All of the analysis was done by SPSS 15 for window.

Based on the result of the findings that has been overviewed in chapter four, the research can be summarized in some points. Firstly, there is a significant difference on the students who were treated by STAD method and those who were treated by conventional method. Students' reading comprehension score in STAD class was higher than students in conventional class. There was significant effect on reading comprehension between those who were treated by STAD and those who were treated by conventional method.

Secondly, there is no significant correlation between teaching treatment and students' reading comprehension when it was viewed from students' level of self esteem, students' self esteem gave minimum contribution toward the difference of reading comprehension score between students who were taught by STAD and students who were taught by conventional method.

Thirdly, there is significant correlation between students' self esteem and students reading comprehension for those who were taught by using conventional method. There was no significant correlation between students' self esteem and students reading comprehension for those who were taught by using STAD method.

Based on the result which showed that STAD give significant effect on improving reading comprehension, it is suggested that English teachers of SMAN 1 Kediri, Tabanan and from other schools to use STAD as the treatment technique in reading class due to the result of this study that proved to improve the students' reading comprehension

Since there is no significant correlation between teaching treatment and reading comprehension when it is viewed from students' level of self esteem, it is expected that other researcher to develop STAD or different treatments or method that can improve students' reading comprehension by considering their self esteem.

\section{REFERENCES}

Andreas, Veronica. 2003. The Influences of Affective Variables on FL/ESL Teaching and Learning. The journal of Imagination in Language Learning and Teaching Vol. VII $01-03$

Brown, H.Douglas. 1980. Principles of Language learning and Teaching. New Jersey: Prentice-Hall, Inc.

Brown, H.Douglas. 1980. Principles of Language learning and Teaching.Fourth Edition. New York, Pearson Longman.

Coopersmith, Stanley. 2005. Coopersmith Self-Esteem Inventories Manual. Retrieved in Wednesday, October 26,2011.from http://www.mindgarden.com/products/cseis.htm 
Cunningham, Anne E; Stanovich, Keith E. 2011. Journal of Direct Instruction. The American Federation of Teachers.

Dantes, Nyoman. 2012. Metode Penelitian. Yogyakarta. Andi Press.

Ellis, Rod. 1997. Second Language Acquisition. Oxford University Press.

Freeman, D Larsen. 2000. Technique and Principles in Language Teaching. Oxford ; Oxford University Press.

Geva, Esther. 2006. Learning to Read in a Second Language: Research, Implications, and Recommendations for Services. Canada: University of Toronto

Grabe, William. 2009. Reading In Second Language ; Moving From Theory to Practice. New York: Cambridge University Press

Huda, Miftahul. 2013. Model-Model Pengajaran dan Pembelajaran. Yogyakarta: Pustaka Pelajar

Koyan, I Wayan. 2012. Statistik Pendidikan ; Teknik Analisis Data Kuantitatif. Singaraja : Universitas Pendidikan Ganesha Press.

Krashen, Stephen D. 1995. The Natural Approach ; Language Acquisition in The Classroom. Prentice Hall Europe.

Murcia, Marianne C. 2001. Teaching English as a Second or Foreign Language. Boston: Heinle \& Heinle

Nevills, Pamela; Wolfe, Patricia. 2004. Building for The Reading Brain. California: Corwin Press

Nutall, Christine.1985.Teaching Reading Skill in A Foreign Language.London:Heinemann

Pang, Elizabeth S; Muaka, Angaluki; Benhardt, Elizabeth. B; Kamil, Michael. L. 2003.Teaching Reading. France: Sadag

Slavin, E.Robert. 2005. Educational Psychology, Theory and Practice. Boston :Pearson Longman

Soureshjani, H Kamal. 2011. An Investigation into the Relationship between Self-esteem, Proficiency Level, and the Reading Ability of Iranian EFL Language Students. Finland : Academy Publisher

TEFLIN journal. 2014. TEFLIN Publication Division. English Department, Faculty of Letters, Universitas Negeri Malang.

Undang-Undang No 20 Tahun 2003 Tentang Sistem Pendidikan Nasional 